\title{
W STRONĘ DEMOKRACJI EKONOMICZNEJ. MIĘDZY SOCJALIZMEM RYNKOWYM A DEMOKRATYCZNYM PLANOWANIEM
}

\author{
DAMIAN WINCZEWSKI
}

\begin{abstract}
Abstrakt: Głównym celem niniejszego artykułu jest odpowiedź na pytanie, jaki model planowania jest możliwy do zastosowania w postkapitalistycznej gospodarce okresu przejściowego, opartej na samorządności pracowniczej. Prace autorów zajmujących się współczesna ekonomia polityczną dowodza, że kooperatywy pracownicze moga stanowić efektywny sposób zarządzania przedsiębiorstwem, a neoliberalny pogląd na funkcjonowanie firm jest anachroniczny. Pat Devine i Fikret Adaman próbowali dowieść, że w pracowniczych przedsiębiorstwach da się przeprowadzić efektywną alokację poprzez planowanie oparte na negocjacji. Paul Cockshott i Allin Cottrell dowodzili z kolei, że elementy politycznej negocjacji są zbędne, ponieważ planowanie wymagać miałoby jedynie rozwiniętej technologii komputerowej oraz rachunku opartego o prawo wartości opartej na pracy. Obydwa modele posiadaja istotne ograniczenia, które stawiaja pod znakiem zapytania ich funkcjonalność. Dowodzę, że lepszym rozwiązaniem problemu efektywnej koordynacji przedsiębiorstw pracowniczych jest wykorzystanie na szeroką skalę planowania indykatywnego, które było w przeszłości stosowane w różnych krajach kapitalistycznych. Zmiana sposobu produkcji i zniesienie własności prywatnej na rzecz własności kolektywnej daje nadzieję, że w socjalizmie planowanie indykatywne będzie funkcjonować lepiej niż w kapitalizmie.
\end{abstract}

Słowa kluczowe: kapitalizm, socjalizm, planowanie, kooperatywy pracownicze, produkcja 


\section{Wprowadzenie}

W ubiegłym wieku ambicją znacznej części socjalistycznych i marksistowskich ekonomistów było stworzenie takiego modelu gospodarczego, który jednocześnie miałby podobna lub większą efektywność niż kapitalizm. Oprócz powstałej w Związku Radzieckim gospodarki centralnie planowanej dużą popularnością wśród ekonomistów cieszyła się koncepcja socjalizmu rynkowego. W swojej pierwotnej wersji socjalizm rynkowy był jedynie pewną modyfikacją gospodarki centralnie sterowanej. Główna różnica polegała na tym, że w klasycznym socjalizmie rynkowym zakładano istnienie rynku konsumpcji i rynku pracy, natomiast alokacja środków produkcji miała być przeprowadzana na podstawie symulacji rynku dokonywanej przez planistów. Najbardziej znanym przykładem takiego rozwiązania jest model Oskara Langego (1973, 244-285).

Niepowodzenia gospodarki centralnie planowanej oraz krytyka propozycji Langego i jemu podobnych doprowadziły do kryzysu w ekonomicznej teorii socjalizmu. W latach osiemdziesiątych poprzedniego stulecia część zachodnich akademickich ekonomistów, głównie brytyjskich i amerykańskich zaczęła tworzyć modele, które można określić mianem nowego socjalizmu rynkowego. Od klasycznej wersji propozycje te odróżnia redukcja roli planowania do minimum i wykorzystanie mechanizmu rynkowego na szeroka skalę, przy jednoczesnym zachowaniu dominującej roli państwowych i kolektywnych form własności. W kolejnych latach na fali krytyki nowego socjalizmu rynkowego zaczęły pojawiać się również propozycje demokratycznego planowania, których celem było wykazanie, że przy zachowaniu demokratycznych procedur racjonalna alokacja zasobów w gospodarce planowej jest możliwa.

Zarówno socjalizm rynkowy, jak i demokratyczne planowanie można rozpatrywać jako teorie demokracji ekonomicznej, rozumianej przeze mnie jako alternatywna struktura ekonomiczna, która pogłębia polityczną równość poprzez redukcję nierówności mających swe źródło w dominującym typie własności i sposobie zarządzania firmami w kapitalizmie.

Oba rodzaje modeli nie spotkały się z szerszym odzewem w czasach gdy powstawały. Zdaniem ich zwolenników stało się to z przyczyn politycznych, tzn. upadek państw realnego socjalizmu sprawił, że niewielu ekonomistów było skłonnych traktować jakiekolwiek propozycje ekonomiczne z „socjalizmem” w nazwie poważnie. Komentarze, które się pojawiały, były zazwyczaj krytyczne - dotyczyły wadliwej metodologii stosowanej przez ekonomistów socjalistycznych oraz niemożliwości pogodzenia planowania z mechanizmem rynkowym.

Moim zdaniem pomimo upływu czasu nie powinno się odrzucać tych propozycji bez rzeczowej dyskusji. Dlatego chciałbym zrekonstruować główne wątki polemiczne dotyczące najciekawszych wedle mojej opinii modeli, a następnie wyciagnnąć wnioski i dokonać 
podsumowania problemów, jakie się z nimi wiąża. Rozpatrywać je będę jako propozycję funkcjonowania gospodarki w okresie przejściowym od kapitalizmu do socjalizmu.

W niniejszym artykule odpowiem na pytanie: jaki typ planowania gospodarczego wydaje się być współcześnie możliwy do zastosowania w gospodarce okresu przejściowego? Czy planowanie da się pogodzić z mechanizmem rynkowym? Problemami pomocniczymi, które chcę rozpatrzyć, sa pytania: jakie formy organizacji pracowniczych powinny dominować w nowym, niekapitalistycznym typie produkcji, jaka może być ich efektywność oraz na ile funkcjonalne są współczesne modele planowania?

W celu przedstawienia odpowiedzi na te pytania przedstawię w skrócie główne problemy dotyczące tematu. Następnie spróbuję wykazać racjonalność socjalistycznego sposobu produkcji opartego na kooperatywach pracowniczych. W dalszej części zajmę się omówieniem dwóch współczesnych modeli demokratycznego planowania - systemu bezpośredniej kalkulacji Paula Cockshotta i systemu opartego na negocjacji Pata Devine'a. Postaram się wskazać ich zalety oraz ograniczenia w kontekście aktualnej wiedzy ekonomicznej. W końcowej części przedstawię wnioski i propozycję ewentualnej alternatywy dla tych projektów.

\section{Gospodarka mieszana czy planowana?}

Poza standardową kwestią kalkulacji ekonomicznej współcześni teoretycy socjalizmu rynkowego muszą borykać się z zaniedbaną w projekcie Langego funkcją przedsiębiorczą i powiązanymi z nią ściśle problemami motywacji i innowacji (Temkin 2008, 69). Zdaniem Włodzimierza Brusa i Kazimierza Laskiego (1992, 92-126) pewnych uzasadnionych historycznie wniosków dotyczących możliwości pogodzenia gospodarki planowej i rynku dostarczyły próby adaptacji mechanizmu rynkowego do potrzeb socjalizmu przez władze państwowe na Węgrzech (1968-1989) i w Jugosławii (1965-1984)ํ․

Węgierski nowy mechanizm ekonomiczny, wskutek paternalistycznego podejścia biurokracji do firm państwowych, nie spowodował znaczących zmian w porównaniu z planowaniem centralnym (1992, 87). Natomiast w Jugosławii mimo odczuwanej przez obywateli poprawy warunków życiowych wzrost gospodarczy z biegiem lat stał się nawet nieco gorszy niż w państwach opartych o gospodarkę centralnie sterowaną. W obu państwach

\footnotetext{
1 Powyższe zdanie wymaga dwóch uzupełnień. W rzeczywistości gospodarka węgierska nie została poddana faktycznemu urynkowieniu. Panowała tam biurokratyczna pionowa koordynacja upodabniająca ją do schematu zarządzania w gospodarce planowej. Występowały również cykliczne okresy „szturmowe”, gdzie przedsiębiorstwa realizowały zadania na podobnej zasadzie co w nakazach wieloletnich planów gospodarczych. W Jugosławii natomiast funkcjonowanie pełnego socjalizmu rynkowego szacuje się na okres 1965-1973, później wprowadzono gospodarkę kontraktową, w znaczny sposób osłabiająca mechanizm rynkowy. Szerzej o tych kwestiach piszą Brus i Laski (1992).
} 
głównym problemem była działalność przedsiębiorstw. Nawet w przypadku nieudolnego zarządzania i przynoszenia strat firmy nie były zamykane bądź poddawane restrukturyzacji, lecz wciąż mogły liczyć na pomoc finansowa państwa. Mimo zachęt ze strony władz w przedsiębiorstwach nie przejawiano chęci do konkurowania i wdrażania innowacji - np. w jugosłowiańskich samorządach pracownicy preferowali przeznaczanie zysków na wzrost wynagrodzeń niż na inwestycje $(1992,110)$. Przywołani powyżej autorzy nie chcieli rozstrzygać ostatecznie, która forma zarządzania własnością powinna dominować w gospodarce socjalistycznej (państwowa czy samorządy robotnicze). Doszli jednak do konkluzji, że planowanie powinno zostać ograniczone do najważniejszych decyzji strategicznych, a gospodarka socjalistyczna powinna działać w sposób możliwie najbardziej zbliżony do gospodarki kapitalistycznej.

Wobec powyższych problemów już na poziomie teoretycznym projekt gospodarki socjalistycznej wymagał znaczącej reformy. Postulowano odejście od gospodarki planowej, konkurencję między państwowymi przedsiębiorstwami, częściową prywatyzację i wprowadzenie kooperatyw pracowniczych, a ponadto implementację rynków kapitałowych i postawienie przedsiębiorstwom wymogu tzw. twardego budżetu, oznaczającego bankructwo nierentownych firm (Lavigne 1989).

Propozycje te zbliżały nowy socjalizm rynkowy do gospodarki mieszanej. Powstało wiele modeli mniej lub bardziej zbliżonych do zasad sformułowanych w artykule Marie Lavinge (Nove 1983; Brus i Laski 1992; Estrin i Le Grand 1989, Miller 1989 i inni). Najbardziej znany z nich, autorstwa Aleca Nove, dopuszczał również na większą skalę firmy jednoosobowe (1983, 200). Zwolennikiem socjalizmu rynkowego był również Janos Kornai, który jednak w dość krótkim czasie zweryfikował swoje poglądy i opowiedział się za pełną gospodarką wolnorynkowa (1990).

Radykalna zmiana podejścia do socjalizmu wywołała uzasadniony opór marksistów. Najbardziej trafna wydaje się krytyka przeprowadzona w latach osiemdziesiątych XX wieku przez Ernesta Mandela (1986,1988). Autor zaznaczył, czym różni się alokacja zasobów poprzez rynek i poprzez planowanie. Otóż alokacja zasobów poprzez rynek jest alokacja pośrednia. Przedsiębiorcy wykorzystuja sygnały dotyczące wahań popytu i podaży, by umieścić swoje zasoby na rynku ex post. Planowanie jest natomiast forma alokacji bezpośredniej ex ante, w ramach której planiści starają się wykorzystać zasoby adekwatnie do posiadanych informacji.

Zdaniem Mandela za demokratyczną gospodarką planową przemawia proces obiektywnego uspołecznienia pracy, jaki dokonuje się w kapitalizmie. Oznacza on rosnąca współzależność procesów pracy oraz produkcji i wyboru dóbr. Efektem tego w gospodarce kapitalistycznej jest powstawanie złożonych, wielobranżowych korporacji. Z uwagi na swoje rozmiary nie dokonuja alokacji prefabrykatów poprzez rynek, lecz czynią to w sposób planowy. Według autora świadczy to o sprzeczności rozwiniętego kapitalizmu - w jego ramach występuje 
zarówno alokacja zasobów poprzez plan, jak i poprzez rynek. Sądził, że prędzej czy później doprowadzi to do implozji kapitalistycznego sposobu produkcji, ponieważ planowanie jest nie do pogodzenia z gospodarką kapitalistyczną. Produkuje ona zbyt wielkie ilości dóbr, zaspokajając nie zawsze istotne potrzeby i przesadnie zwiększając konsumpcję. W przeciwieństwie do zwolenników socjalizmu rynkowego uważał, że gospodarka oparta w całości na planowaniu jest możliwa, ponieważ w socjalizmie będzie można racjonalnie ustalić hierarchię ludzkich potrzeb, a w związku z tym produkować ograniczoną (możliwą do kalkulacji ex ante) liczbę produktów, które zaspokajałyby potrzeby będące najwyżej w tej hierarchii. Tym samym wyeliminowane miałoby być marnotrawstwo typowe dla kapitalizmu. Stopniowo wskutek zracjonalizowanego procesu produkcji obfitość dóbr miałaby wzrastać na tyle, że zaspokajane byłyby również potrzeby niższego rzędu. Ostatecznie prowadzona dla zysku produkcja towarowa miałaby całkiem zaniknąć.

Belgijski marksista nie miał za to zaufania do socjalizmu rynkowego. Jego zdaniem jest to kolejna forma regulacji gospodarki kapitalistycznej, która z góry skazana jest na niepowodzenie. Wskazywał, że samo użycie mechanizmu rynkowego prowadzi do zaburzenia hierarchii potrzeb - działanie praw rynkowych sprawia, że produkowane są dobra nie najpotrzebniejsze, ale najbardziej opłacalne. Na tej podstawie poddał krytyce sposób funkcjonowania firm w socjalizmie rynkowym, ponieważ miałyby być nastawione na zysk. Zdaniem autora prowadziłoby to do eliminacji słabszych firm z rynku i centralizacji kapitału, czego skutkiem byłoby powstawanie monopoli. Co więcej, siła nabywcza i zagregowany popyt byłyby w dalszym ciąu nierówno podzielone. Osoby majętne ze swoją siły nabywczą miałyby większy wpływ na produkcję niż popyt ze strony uboższej części społeczeństwa. Oznaczałoby to, że produkcja byłaby nakierowana na szybki zysk (np. budowa domów dla osób majętnych), a nie na ważne potrzeby społeczne (np. budownictwo komunalne).

Największy problem z teorią Mandela polega na tym, że jakkolwiek autor ten ma wiele racji krytykując wizje socjalizmu oparta na rynku, to należałoby w zamian zaproponować koherentny i możliwy do realizacji projekt nierynkowy. Autor proponował cykliczne zjazdy delegatów robotniczych, pracowniczych i ludowych, którzy mieliby zająć się podziałem dochodu narodowego. Następnie mieliby oni opracowywać plan na podstawie bilansów materiałowych z poszczególnych zakładów. Niestety propozycja ta jest bardzo ogólna. Nie wiadomo, jak w szczegółach miałaby odbywać się kalkulacja ekonomiczna oparta na bilansie materiałowym - autor wspomina jedynie o użyciu komputerów i tabel przepływów międzygałęziowych. Nie jest również jasne, na ile drobiazgowe miałoby być planowanie i czy byłoby oparte na jakimś wcześniej danym modelu wzrostu. Z propozycji autora zdaje się wynikać, że wszelkie decyzje ekonomiczne odbywałyby się w drodze głosowań, bez informacji, jak długa deliberacja by je poprzedzała i czy dochodziłoby do konsultacji z ekspertami oraz przedstawicielami konsumentów. Dlatego oponenci Mandela poniekąd słusznie zauważyli, że 
sformułowane przez niego zasady demokratycznego planowania były tylko zbiorem postulatów (Nove 1991, 229-232). Choć mogą być one źródłem inspiracji dla trockistowskich ekonomistów, to w zaprezentowanej postaci trudno jest je traktować jako wyczerpująca propozycję ekonomiczna.

Wobec tego zamierzam w ramach tego artykułu więcej uwagi poświęcić nowszym, bardziej rozbudowanym propozycjom ekonomistów socjalistycznych. Myślę, że trzeba przy tym wziąc pod uwagę lekcje, jakie płyną z polemiki Mandela ze zwolennikami socjalizmu rynkowego. Po pierwsze, nie można przeceniać mechanizmu rynkowego jako jedynego skutecznego mechanizmu alokacji zasobów, a po drugie, trzeba przeprowadzić analizę zalet i wad modeli planowania w kontekście współczesnych prac lewicowych ekonomistów. Wcześniej chciałbym jednak rozpatrzyć, jak możliwa jest sugerowana przez autora gospodarka oparta na samorządności pracowniczej (Mandel 1986) oraz czy socjalistyczny sposób produkcji może osiagnąć przewagę nad tradycyjnymi, kapitalistycznymi formami organizacji pracy. Samoorganizacja pracowników jest współcześnie powszechnie akceptowanym postulatem większości rzeczników zastapienia gospodarki kapitalistycznej przez gospodarkę socjalistyczną. Dlatego też uważam, że w kontekście późniejszych rozważań warto omówić tę kwestię.

\section{Samorządność pracownicza i socjalistyczny sposób produkcji}

W czasach gdy powstawały nowe wersje socjalizmu rynkowego, większość autorów opierała swoje modele w większym lub mniejszym stopniu na kooperatywach pracowniczych (Devine 1992). Porażki państwowych przedsiębiorstw w realnym socjalizmie oraz uzasadniona nieufność wobec własności prywatnej zdawały się wówczas przemawiać za przyjęciem takiego rozwiązania.

Odmienne koncepcje zaprezentowali Parnab Bardhan i Joe Roemer (1992, 1993). Propozycje obu autorów oparte były na indywidualizmie i subiektywizmie metodologicznym zgodnym z neoklasyczną wykładnią ekonomii. Obaj sądzili, że firmy w ich modelach mogłyby działać na identycznych zasadach co firmy kapitalistyczne - miałyby być zarządzane przez menadżerów maksymalizujących zyski i minimalizujących straty. W ujęciu Bardhana firmy miały łączyć się i funkcjonować jak japońskie kairetsu - grupy kredytujących się nawzajem przedsiębiorstw tworzących wielobranżowe korporacje skupione wokół centralnego banku, który mógłby w znacznym stopniu kontrolować ich poczynania. Z kolei w wersji Roemera zarządy firm miałyby być kontrolowane przez udziałowców - obywateli posiadających akcje instytucji rynku kapitałowego, od których firmy byłyby zależne. Ogólny kierunek rozwoju gospodarki miałby być koordynowany przez planowanie gospodarcze oparte na właściwie identycznych zasadach co planowanie indykatywne we Francji po II wojnie światowej (Milonakis 2003). 
Tę koncepcje poddano jednak gruntownej krytyce. Po pierwsze, nie rozwiązuje ona problemu agentów i przełożonych. Problem ten dotyczy kwestii, jak pogodzić rozbieżne interesy agenta (np. pracownika) i przełożonego (np. pracodawcy). Na gruncie teorii socjalizmu problem dotyka kwestii tego, że menadżerowie prowadzący socjalistyczne firmy realizują często cele prywatne, a nie społeczne (to społeczeństwo odgrywa rolę przełożonego). Krytycy wskazuja (Temkin 2008, 70-75), że literatura dotycząca problemu agent-przełożony miała charakter wyłącznie opisowy, odnoszący się do funkcjonowania korporacji w kapitalizmie, natomiast Bardhan i Roemer formułowali twierdzenia o charakterze normatywnym. Po drugie, podobnie jak Lange, Bardhan i Roemer postrzegali rynek i konkurencję w statycznym, właściwym ekonomii neoklasycznej ujęciu, podważanym obecnie zarówno przez marksistów, jak i szkołę austriacką - autorzy błędnie zakładali, że menadżerowie firm będą funkcjonować jak automaty maksymalizujące zyski, funkcjonując jednocześnie na zasadach konkurencji doskonałej. Modele te posiadają również inne pomniejsze ograniczenia opisane we współczesnej literaturze (Andreani 2008). Moim zdaniem w ujęciu Bardhana i Roemera socjalizm rynkowy w praktyce nie różni się od kapitalizmu - kopiuje bez żadnych modyfikacji rozwiązania stworzone na potrzeby państw kapitalistycznych. Zakłada w praktyce jedynie zwiększenie interwencjonizmu oraz wpływu obywateli na politykę gospodarczą państwa

W ostatnich latach powstało kilka prac, które dostarczyły argumentów pokazujących, że kooperatywy pracownicze mogą działać efektywnie poza systemem kapitalistycznym. Geoffrey Hodgson (2005a) twierdził, że współczesna ekonomia wiedzy obala neoliberalne mity na temat funkcjonowania przedsiębiorstw, których podstawa jest teza, że jednostka najlepiej osądza swoje własne interesy. Na polu ekonomicznym ma się to najlepiej wyrażać w dominacji własności prywatnej i transakcjach rynkowych. Autor twierdzi, że gdyby firmy miały działać w sposób rynkowy, to umowy pomiędzy zatrudniającymi a pracownikami miałyby w przeważającej mierze formę umów o dzieło. Tymczasem formy zatrudnienia najczęściej nie maja charakteru kontraktów podobnych do tych zawieranych na rynku. Wśród osób zatrudnionych przeważaja umowy o pracę. Proces produkcji bazuje na rozproszonej, niemożliwej do skodyfikowania, milczącej wiedzy, którą trudno sprowadzić do kolejnego towaru. Złożoność wiedzy sprawia, że zarówno pracownicy, jak i menedżerowie nigdy do końca nie są świadomi wszystkich szczegółów tego procesu. Dlatego też umowy o pracę dominują, bo nie wskazują wszystkich detali zadań, które mają być wykonywane w miejscu pracy.

Wiedza natomiast ma charakter społeczny. Mylące sformułowanie „kapitał ludzki” sugeruje, jakoby wiedza i umiejętności miały być towarem podlegającym prawom rynkowym. Są one jednak tworem zależnym od lokalnych i kulturowych kontekstów, nigdy więc nie moga nabrać w pełni cech towaru. Ekonomia głównego nurtu nie docenia znaczenia akumulacji wiedzy technicznej. Jest ona czymś więcej niż tylko sumą wiedzy poszczególnych jednostek 
(Adaman, Devine 2002a). Bez niej produkcja jest niemożliwa. Ze względu na społeczny charakter wiedzy nie do przyjęcia okazuje się założenie neoliberałów o supremacji indywidualnych przedsiębiorców w zarządzaniu firmą (Hodgson2005a).

Fikret Adaman i Pat Devine (2002) stwierdzili, że przedsiębiorcze działania w przypadku kolektywnych zrzeszeń pracowników, poddanych demokratycznemu zarządzaniu, moga być bardziej efektywne niż działania kapitalistycznych firm. Wynikać by to miało z natury samej przedsiębiorczości, która ma charakter społeczny. Autorzy zakładali, że w partycypacyjnym modelu zarządzania firmą przedsiębiorczość staje się bardziej inkluzywna, co umożliwia lepsze wykorzystanie różnych rodzajów wiedzy - od jawnej i niejawnej do milczącej. Lepszą wydajność miałoby zapewnić zdecentralizowane, oparte na negocjacji planowanie, dzięki któremu firmy mogłyby działać wspólnie, a nie pojedynczo jak w kapitalizmie.

Ważne, choć nieco odmiennie od poglądów Adamana i Devine’a spojrzenie na rolę kooperatyw jako fundamentu socjalizmu rynkowego zaprezentował w swojej pracy Bruno Jossa (2012). Autor przyjął za Jaroslavem Vankiem (1971) rozróżnienie na dwa rodzaje kooperatyw pracowniczych. Pierwszym rodzajem są firmy określone mianem worker management firms - WMF, oparte na samofinansowaniu pracowników. Prowadzona w tych firmach rachunkowość nie rozróżnia dochodów pochodzacych z pracy i kapitału. Drugim rodzajem są labour management firms - LMF. Tego rodzaju przedsiębiorstwa są finansowane pożyczkami, a ich celem jest zwiększenie dochodu przypadającego na pojedynczego pracownika. Jossa twierdzi, że drugi rodzaj firmy może stanowić podstawę nowego sposobu produkcji. Oparcie systemu na przedsiębiorstwach typu LMF miałoby doprowadzić do odwrócenia relacji między pracą i kapitałem - ponieważ w tym przypadku to nie kapitaliści wynajmują pracowników, ale to pracownicy „wynajmuja” kapitalistów - podejmuja samodzielne decyzje o losach swoich spółek i pożyczają kapitał od banku (kapitalistów).

W nowym systemie produkcji firmy te miałyby ze sobą konkurować, lecz w inny sposób niż w kapitalizmie. Autor sądzi, że pracownikom uda się zachować pozytywne elementy konkurencji kapitalistycznej, takie jak innowacyjność, postęp techniczny i rosnące zyski. Zarazem jednak w nowym systemie konkurencja ma być mniej agresywna, zaś ryzyko bankructwa firm zostaje zredukowane do minimum. Jossa argumentuje, że dobrze opłacani pracownicy kooperatyw typu LMF mieliby tendencję do konkurowania i zwiększania swoich zarobków, jednakże odwrócenie relacji między płacą i kapitałem prowadzić miałoby do zaniku pracy najemnej (brak kapitalistów mogących zatrudniać), a w rezultacie do zniesienia zjawiska alienacji pracy. W związku z tym pracownicy władający firmami chcąc polepszyć swój status rywalizowaliby ze soba, lecz nie byliby nastawieni na wyniszczenie konkurencji, ponieważ wolni od alienacji w ostatecznym rozrachunku liczyliby się z dobrem i interesami innych ludzi (Jossa 2014a). 
Jossa stawia tezę, że przejęcie produkcji przez pracowników i nowy, wyzbyty antagonizmów rodzaj konkurencji oznacza de facto zwycięstwo socjalizmu, nawet gdy nie uda się socjalistom przejać pełnej władzy nad państwem, ponieważ praca dominowałaby nad kapitałem (2012). Tym samym kooperatywy oparte na modelu LMF stają się nową wersją socjalizmu rynkowego. Jest to wizja radykalnie różniąca się od większości poprzednich, które zakładają pewną formę kontroli państwowej nad rynkiem i produkcją.

Z perspektywy marksistowskiej propozycja Jossy może zdawać się kontrowersyjna. Niektórzy, tak jak Antonio Gramsci, przejawiali pozytywne nastawienie do koncepcji kontroli pracowniczej nad produkcją. Włoski myśliciel odrzucał jednak alokację poprzez rynek, a kooperatywy traktował jako element składowy gospodarki planowanej. Samą zmianę trybu produkcji rozumiał raczej jako rewolucyjne przejęcie władzy, choć nie odrzucał całkowicie zalet zmian opartych na demokracji (Jossa 2009). Spora część marksistów była też sceptycznie nastawiona do samej idei oddania firm w ręce pracowników. Sądzono, że w rezultacie pracownicy staną się kapitalistami. Jossa twierdzi, że sceptycyzm ten brał się z tego, że do czasów Vanka przeważały koncepcje kooperatyw typu WMF. Takie przedsiębiorstwa byłyby narażone na ciagłe niedokapitalizowanie i nie stanowiły gwarancji przejścia do nowego sposobu produkcji. Oprócz tego w pracach zarówno Marksa jak i Lenina - zdaniem autora - można znaleźć liczne dowody poparcia dla koncepcji kooperatyw pracowniczych (Jossa 2005). Szerzej swoja koncepcję autor rozwija w pracy Cooperative Firm as New Mode of Production (Jossa 2014b).

Musimy w tym miejscu uzupełnić powyższe rozważania. Wydaje się, że kooperatywy pracownicze powinny stanowić podstawę i gwarancję efektywności socjalizmu rynkowego. Jednak zasięg firm opartych na kooperacji pracowniczej jest ograniczony. Jak wskazuje Malesson (2012, 74-76), w niektórych branżach nie da się całkowicie wprowadzić tego typu zarządzania. Istnieje szereg branż kluczowych dla funkcjonowania całego społeczeństwa, takich jak poczta, placówki oświatowe, szpitale itd., które powinny być własnościa publiczna podobnie jak firmy odpowiedzialne za dostawy energii, bieżącej wody czy transport. W związku z tym nie można odrzucić jakiejś formy centralnej koordynacji tego typu przedsiębiorstw.

Sam Jossa uważa promowaną przez siebie koncepcję firmy typu LMF za komponent możliwy do pogodzenia z modelami nowego socjalizmu rynkowego zaprojektowanymi w poprzednich latach, a także tymi, które być może dopiero będą stworzone (Jossa 2014a). W świetle przytoczonej wyżej krytyki Mandela fundamenty, na których oparte są te modele moga wydawać się dyskusyjne. Proponuje zatem, przyjrzeć się bliżej dwóm modelom demokratycznego planowania, w których rola mechanizmu rynkowego miałaby być ograniczona. 


\section{Planowanie zdecentralizowane oparte na negocjacji}

Pat Devine (1988) stworzył model planowania, w którym zarządzane przez robotników firmy miałyby być koordynowane poprzez oddolny proces negocjacji. Wraz ze swoim uczniem Fikretem Adamanem byli przekonani, że ich propozycja oznaczać będzie zerwanie z niedoskonałościami socjalizmu rynkowego. Omówię poniżej ich założenia.

Devine (1992) sądził, że mechanizm istniejących modeli socjalizmów rynkowych oparty jest na wymianie rynkowej i siłach rynkowych. Wymiana rynkowa zakłada transakcje pomiędzy kupującymi i sprzedawcami, którzy wymieniają się usługami oraz dobrami produkowanymi przez przedsiębiorstwa. Siły rynkowe odpowiadają za proces alokacji zasobów koordynowanego ex post. Mechanizm pierwszego typu odpowiedzialny jest za wytwarzanie informacji o stanie popytu i podaży oraz umożliwia aktorom rynkowym zorientowanie się we własnej sytuacji. Natomiast drugi element odpowiedzialny jest za niezależność decyzji podmiotów produkcyjnych i podejmowane działania inwestycyjne. Autor twierdzi, że siły rynkowe prowadza do rozumianej po marksowsku ,anarchii produkcji” i socjalizm rynkowy nie jest w stanie poradzić sobie z tym mechanizmem. Ponieważ funkcja ta - jego zdaniem skutkować będzie obniżeniem efektywności produkcji, to należy odrzucić gospodarkę oparta na siłach rynkowych i przejść do planowania opartego na ogólnospołecznej partycypacji.

Devine podzielał poglądy ekonomistów opisane w sekcji drugiej niniejszego artykułu, to znaczy uważał, że przyszłe społeczeństwo socjalistyczne powinno być oparte na samorządnych przedsiębiorstwach, konkurujących ze sobą i zarządzanych przez reprezentantów załóg. Co więcej, produkcja w socjalizmie może być bardziej efektywna niż w kapitalizmie (Devine 2002). Brytyjski ekonomista - podobnie jak Malesson, Jossa i inni zwolennicy socjalizmu rynkowego sądzi, że konieczna jest wymiana rynkowa pomiędzy kooperatywami pracowniczymi i innymi przedsiębiorstwami. Jednak Devine twierdzi, że w celu uniknięcia patologii kapitalistycznego systemu produkcji należy znieść siły rynkowe na rzecz alokacji ex ante, a konkretnie planowania opartego na negocjacjach społecznych. Ich model miałby być kombinacją bezpośredniej i reprezentatywnej demokracji ekonomicznej. Ludzie poprzez proces politycznych negocjacji mieliby wybierać pomiędzy alternatywnymi planami rozwoju ekonomicznego na określony czas. Plany te uwzględniałyby kwestie:

\footnotetext{
(...) balansowania inwestycji na cele społeczne i ekonomiczne, społecznej i indywidualnej konsumpcji, główny rozwój najważniejszych instytucji kulturalnych, urbanistycznych, środowiskowych i transportowych, geograficznej dystrybucji aktywności ekonomicznej, priorytetów w alokacji zasobów oraz innowacjach i tak dalej (2002b).
} 
Planowaniem inwestycji zajmować miałyby się specjalne komitety „negocjacyjnej koordynacji”, które wdrażałyby postanowienia planu na szczeblach regionalnym, krajowym i międzynarodowym. W komisjach tych mieliby zasiadać reprezentanci nie tylko producentów, lecz również organizacji konsumentów i innych organizacji, których interesy zależne są od realizacji planu (Devine 1992). Rezultatem uczestnictwa w procesie alokacji zasobów przedstawicieli zainteresowanych podmiotów miałoby być wypracowanie wspólnej, respektującej pluralistyczne poglądy i interesy polityki ekonomicznej.

Próba zdystansowania się od socjalizmu rynkowego w modelu Devine’a jest dyskusyjna. W swoich pracach podkreśla wage wymiany rynkowej, która obejmuje rynek konsumpcji i rynek pracy zupełnie jak w klasycznych wizjach socjalizmu rynkowego. Mimo swej deklarowanej niechęci - autor akceptuje i adaptuje na potrzeby swojego projektu pewna wersję mechanizmu rynkowego.

Co więcej, rozróżnienie pomiędzy wymianą rynkową a siłami rynkowymi jest wątpliwe pod względem swojej funkcjonalności. Devine nie stworzył wyraźnego kryterium demarkacji pomiędzy obydwoma pojęciami. Zdaniem Goeffreya M. Hodgsona (2005b), który przeanalizował przykłady funkcjonowania współczesnych wielkich korporacji, na bazie definicji Devine’a niemożliwe jest precyzyjne określenie, w jakich przypadkach o planowaniu nowych inwestycji decyduja siły rynkowe, a w jakich wymiana rynkowa. Devine i Adaman (2006) nie byli w stanie konkretnie odnieść się do tego zarzutu. Swojemu krytykowi zarzucili niezrozumienie ich intencji. Moim zdaniem krytyka Hodgsona jest trafna i zaproponowany przez Devine'a podział na wymianę rynkowa i siły rynkowe ma arbitralny charakter. W rzeczywistości rozróżnienie to nie jest tak istotne. W praktyce w wielu przypadkach sama obecność wymiany rynkowej wiąże się z oddziaływaniem konkretnych sił popytu i podaży. Natomiast fundamentalne organizacje współczesnego kapitalizmu, takie jak monopole i oligopole, choć funkcjonuja poza zasięgiem sił rynkowych (Hodgson 1998), to jednak nie podważają one istniejącego sposobu produkcji oraz alokację zasobów wciąż dokonuja poprzez rynek. W związku z tym założenia przyjęte przez Devine’a i Adamana nie moga oznaczać negacji koordynacji rynkowej, która w ich modelu de facto wciąż odgrywa ważną rolę.

Rozważyć należy również zakres kompetencji komitetów „negocjacyjnej koordynacji”. Autorzy w reakcji na krytykę przyznają, iż nie każda decyzja dotycząca produkcji i przyszłych inwestycji może być przedmiotem deliberacji (Adaman i Devine 2001). Hodgson (1998) zarzucił, że podejmowanie zbyt wielu decyzji odnośnie inwestycji i innowacji oznacza statyczną wizję rynku oraz niesie ze sobą zagrożenie rosnącej biurokratyzacji. Rynek jest dynamiczny i dlatego wymaga podejmowania szybkich decyzji w odpowiedzi na nieustannie zmieniające się sygnały. Dlugotrwały proces decyzyjny spowodowałby, że komitety „negocjacyjnej koordynacji” nie nadążałyby za zmianami na rynku. Sprawność oddziaływania sieci komitetów może być również ograniczona geograficznie i terytorialnie. Badania nad gospodarką sieciową 
pokazuja, że współpraca pomiędzy podmiotami gospodarczymi najlepiej układa się na obszarach silnie zurbanizowanych (Nijkamp 2000). Problematycznie zatem może wyglądać koordynacja na rozległych, słabo rozwiniętych terenach.

Oprócz tego najważniejszą kwestią jest zdaniem Hodgsona problem wiedzy milczącej (tacit knowledge). Ludzie w swoich działaniach gospodarczych posługują się specyficznym rodzajem wiedzy, intuicjami których nie da się explicite wyartykułować. Michael Polanyi (1967) stwierdził, że „wiemy więcej niż jesteśmy w stanie powiedzieć”. Problemem, jaki się zatem pojawia, jest sposób, w jaki członkowie komitetów planistycznych mieliby deliberować o rzeczach znanych jednostkom (bądź grupom), lecz niemożliwym do wyartykułowania (Hodgson 1998). Wiąże się z tym również znany problem informacji - czy komitety będą w stanie poradzić sobie z ogromem wiedzy o różnorakich produktach, trudnej do obliczenia liczbie możliwych propozycji inwestycji oraz innowacji?

Adaman i Devine trafnie zauważyli, że znajomość i użycie wiedzy milczacej przysługuje nie tylko przedsiębiorcom, ale przede wszystkim pracownikom (2001).W istocie sam proces deliberacji w komitetach planistycznych nie musi być statyczny i sprowadzać się do obrony stanowisk wcześniej założonych przez uczestników dyskusji. Autorzy wierzyli, że aktywna partycypacja w dyskusji nad planowaniem zmusi deliberujące strony do rewizji wcześniejszych założeń i wyzwoli ich potencjał do twórczego wykorzystania posiadanej wiedzy. Innymi słowy koordynacja oparta na negocjacji ma powodować społeczną mobilizację wiedzy milczącej (2006). Autorzy naiwnie zakładaja, że przedstawiciele różnych grup porzucą bez walki swoje partykularne interesy na rzecz deliberacji i konsensusu. W istocie dialog jest im potrzebny, jednak szybkość podejmowania decyzji dotyczących nowych inwestycji i wydajność tych decyzji wydają się problematyczne. Nie oznacza to oczywiście, że koncepcję koordynacji opartej na negocjacji należy porzucić tylko ze względu na nadmiar informacji. Planowanie partycypacyjne z pewnością ma swoje ograniczenia. Jednak zdaniem krytyków obecny status quo nie jest lepszy, ponieważ rynek kapitalistyczny w wielu przypadkach raczej blokuje niż ułatwia przepływ informacji (Konings 2001).

Przerzucenie całości ciężaru alokacji zasobów na komitety „negocjacyjnej koordynacji”, tudzież inną instytucje demokratycznego planowania powyżej szczebla lokalnego wydaje się mimo wszystko zbyt radykalnym krokiem, przynajmniej na etapie gospodarki fazy przejściowej z kapitalizmu do socjalizmu. Koncepcja ta posiada jednak pewne zalety, które sa widoczne zwłaszcza z punktu widzenia zwolenników zielonego socjalizmu. Możliwość partycypacji w procesie decyzyjnym dotyczącym nowych inwestycji i alokacji dostępnych zasobów daje organizacjom proekologicznym znacznie większe możliwości niż system rynkowy. Planowanie, w którym głos mają nie tylko swobodne zrzeszenia producentów, lecz także konsumenci zaniepokojeni o stan środowiska naturalnego daje szanse na „redefinicję drogi i celów socjalistycznej produkcji w ekologicznych ramach” (Löwy i Kovel 2005). Zdaniem 
Löwy’ego (2007) przejście do socjalizmu zakłada nie tylko nowy sposób produkcji ale także nowy sposób życia, w którym producenci i konsumenci nie będą kierować się wyłącznie zyskiem, lecz również na drodze procesu deliberacji będą mieli szansę nabycia ekologicznej świadomości. Okres przejściowy ma być wstępem do nowej cywilizacji, w której dominuje troska o dobro wspólne, czyli również o przyrodę.

Demokratyczne, partycypacyjne planowanie z udziałem różnych grup społecznych ma więc duży potencjał edukacyjny. Uczestnikom procesu planowania zależałoby nie tylko na zaspokajaniu potrzeb, ale też na trosce o środowisko naturalne. $\mathrm{Na}$ pewno komitety „negocjacyjnej koordynacji” mogłyby pełnić funkcję organów podejmujących ważne decyzje dla środowiska i lokalnych społeczności. Przy ich pomocy możliwe byłoby planowanie inwestycji w infrastrukturze ekologicznej oraz zapobieganie podejmowanym przez przedsiębiorstwa inwestycjom, które niosłyby ze sobą ryzyko zagrożenia dla środowiska naturalnego.

Oprócz walorów dla ekosocjalizmu nie można również zapominać, że tego typu planowanie jest atrakcyjne dla konsumentów i innych środowisk niezwiązanych bezpośrednio ze sferą produkcji. Możliwość postulowania w komitetach rozwiązań o innowacyjnym charakterze i proponowania nowych inwestycji pobudza społeczną aktywność jednostek i całych grup, a jednocześnie stwarza możliwość wytworzenia nowych bodźców dla gospodarki. Z drugiej strony nadmiar bodźców i przepływu informacji może grozić paraliżem instytucji planistycznych. Problem nadmiaru danych i decyzji do podjęcia można rozwiązać dwojako. Jedną z możliwości jest zwiększenie roli rynku w alokacji zasobów. Możliwa jest też centralizacja i wykorzystanie rozwijającej się technologii w celu usprawnienia planowania. W kolejnej sekcji przyjrzymy się tej drugiej opcji.

\section{Nowoczesne technologie komputerowe}

Oskar Lange w swojej pracy Maszyna liczaca i rynek $(1973,336)$ doszedł do wniosku, że problem kalkulacji ekonomicznej był problemem uwarunkowanym historycznie. Jego zdaniem sformułowany przez Friedricha von Hayeka problem nadmiaru danych i równań potrzebujących rozwiązania będzie w niedalekiej przyszłości możliwy do rozwiązania dzięki superszybkim komputerom. Fiasko dotychczasowych modeli centralnego planowania spowodowało, że wielu socjalistów z nadzieją spojrzało na postęp w technologii. Inspirowany przez Langego szkocki informatyk Paul Cockshott wspólnie z Allinem Cottrellem stworzył model centralnego planowania oparty na kalkulacji przeprowadzanej przez komputery (1993). Podobnie jak w koncepcji polskiego ekonomisty, w modelu Cockshotta i Cottrella istnieje rynek pracy i konsumpcji, natomiast rynek czynników produkcji jest symulowany - tym razem nie za 
pomoca Walrasowskiego tatonnement (Walker 1987), lecz komputerowych równań opartych na odwróconych tabelach przepływów międzygałęziowych Leontiewa i algorytmach Gaussa (Cockshott i Cottrell 1989). Istotną różnica między modelem autorów a koncepcją Langego jest całkowite odrzucenie neoklasycznej metodologii, która nie wytrzymała próby czasu i siły argumentów austriackich ekonomistów (Lavoie 1985). Autorzy zaproponowali za to powrót do teorii wartości opartej na pracy. W swoich pracach $(1989,1993)$ wykazali, że za pomoca technologii komputerowej jest możliwa kalkulacja ekonomiczna oparta o jednostki czasu pracy.

Pomysł autorów jest bliski koncepcji innego uczestnika historycznego sporu o kalkulację ekonomiczna w socjalizmie - Charlesa Bettleheima. Francuski ekonomista krytykował politykę gospodarczą Związku Radzieckiego i podobnie jak autorzy twierdził, że w gospodarce planowej powinno obowiązywać obiektywne prawo wartości oparte o czas pracy (1961, 30-31). Zdaniem autora było to jedyne możliwe rozwiązanie problemu ustalania cen w socjalistycznej gospodarce. Prawidłowość kalkulacji w oparciu o jednostki czasu pracy na gruncie ekonometrii starał się udowodnić również Branko Horvat (1989).

Autorzy uważaja, że przy użyciu współczesnej mocy komputerów, pomimo ogromnej wielkości i zróżnicowania współczesnej gospodarki możliwe jest obliczenie wymiernej wartości każdego produktu w społecznie niezbędnym czasie pracy, w ciągu zaledwie kilku minut (2006). Bazując na obliczonym przez zaawansowane technologicznie komputery czasie pracy zawartej w każdym produkcie, sugeruja, aby wprowadzić redystrybucję opartą na certyfikatach (bonach) pracy. Certyfikaty te zawierałyby informację o sile roboczej wytworzonej przez dana jednostkę w danym okresie rozliczeniowym. Byłyby wymienialne na produkty, które posiadałyby kody oznaczające ilość ucieleśnionych w nich jednostek pracy. Autorzy twierdzą, że certyfikaty nie byłyby pieniędzmi, ponieważ każdy certyfikat można byłoby wykorzystać do wymiany na określone dobra tylko jednorazowo.

Cockshott i Cottrell założyli następnie, że wolumen produkcji każdego z produktów wyznaczany byłby poprzez stosunek ilości kwot zawartych w certyfikatach pracy oferowanych za kupno produktu a ilości czasu pracy zawartej w produkcie. Innymi słowy produkcja byłaby zwiększana w przypadku, gdy cena produktu była większa niż ilość zawartej w nim pracy, zmniejszana zaś przy odwrotnym stosunku (2005, 143). W odróżnieniu od zwolenników planowania negocjacyjnego, Cockshott i Cottrell są przeciwni demokracji opartej na deliberacji i wyborach $(2005,246)$. Jednocześnie deklarują się jako orędownicy demokracji bezpośredniej, która polegać miałaby na tym, że obywatele w lokalnych komitetach głosowaliby nad projektami inwestycji. Metoda kalkulacji ekonomicznej preferowana przez autorów miałaby sprzyjać demokracji, ponieważ jednostki czasu pracy byłyby wartością czytelną dla każdego obywatela (1993, 167-170).

Pomimo tego ambiwalentnego stosunku do demokracji wydaje się, że ta koncepcja centralnie planowanej gospodarki posiada ważne zalety. Pierwszą jest unifikacja jednostek 
wymiany towarowej. Drugą natomiast zdaje się być ostateczne rozwiązanie problemu kalkulacji ekonomicznej. Alejandro Agafonow (2012) uważa, że autorzy obalili argumentację Hayeka i za pomocą kalkulacji opartej na społecznie niezbędnym czasie pracy da się stworzyć koherentny model alokacji zasobów w gospodarce socjalistycznej. W jego interpretacji prace Cockshotta i Cottrella stanowia podstawę do budowy socjalizmu w wersji zbliżonej do modelu Langego, socjalizmu, w którym podobnie jak w modelu polskiego ekonomisty rywalizowaliby ze sobą menedżerowie państwowych firm, zaś za realokację społecznie niezbędnego czasu pracy odpowiadałby centralny urząd planistyczny².

Koncepcja planowania proponowana przez autorów może mieć poważne, niezamierzone przez nich konsekwencje dla gospodarki socjalistycznej. Wbrew ich intencjom oraz pomimo silnej centralizacji i zniesienia pieniądza ich model, tak jak model Langego, jest wciąż oparty na pewnej imitacji mechanizmu rynkowego, tylko że symulowanego przez komputery. Wprowadzanie kalkulacji opartej na czasie pracy czyni reprodukcję warunków rynkowych nie mniej uciążliwa, niż w innym modelach socjalizmu rynkowego. Oparcie redystrybucji na certyfikatach pracy nie czyni społeczeństwa bardziej egalitarnym. W końcu zmiana sposobu wyceny pracy z subiektywnej i arbitralnej na „obiektywna” nie znosi podziałów klasowych, nierówności szans i innych patologii systemu rynkowego. Wyraźnie dostrzegają to nawet przedstawiciele austriackiej szkoły ekonomii. Lew Brewster z ironią zauważył i opisał możliwy wyzysk konsumentów przez planistów (którzy jego zdaniem posiadaliby uprzywilejowana pozycję względem reszty społeczeństwa), mogący prowadzić do wybuchu rewolucji i zmiany porządku społecznego (2004). Cockshott wydaje się dość skutecznie bronić samej możliwości kalkulacji w swoim i Cottrella modelu (2009). Jednak faktem jest, że model autorów jest bardzo stechnicyzowany i właściwie demokracja czy jakikolwiek ustrój polityczny wydają się zbędnym dodatkiem. Nawet jeżeli uznać słuszność kalkulacji na podstawie czasu pracy, to alokacja zasobów na tej podstawie w gospodarce okresu przejściowego naszym zdaniem jest nazbyt radykalna i może komplikować sam proces transformacji gospodarki, ponieważ rozwarstwienie spowodowane różnicami w dochodach przedstawicieli różnych zawodów blokuje naszym zdaniem przejście do społeczeństwa, w którym praca najemna zostanie ostatecznie zniesiona. O wiele bardziej rozsądne wydają się propozycje, by zachować gospodarkę towarowo-pieniężną, zaś redystrybucję i likwidację różnic klasowych oprzeć na rozszerzaniu strefy bezpłatnych świadczeń i usług (Husson 2011, 147-151).

Zdaniem Hodgsona (1998) model brytyjskich entuzjastów centralnego planowania w dalszym ciąu jest wystawiony na klasyczną austriacką krytykę dotyczącą kwestii innowacji

\footnotetext{
2 Pomysł, by przyszłą socjalistyczną gospodarkę oprzeć na certyfikatach i bonach pracy, musi wydawać się kontrowersyjny, jeżeli wziąć pod uwagę niedawne koncepcje pracy niematerialnej i produkcji biopolitycznej (Hardt i Negri 2005, 2012). Omawiany model w ogóle nie bierze tych koncepcji pod uwagę i nie wykracza poza klasyczną Marksowską teorię wartości opartej na pracy.
} 
oraz wiedzy milczącej. W centralnie planowanej gospodarce, nawet przy zastosowaniu nowoczesnej techniki (Cockshott i Cottrell 1993, 90) problemem pozostaje kwestia bodźców, dzięki którym planiści wprowadzaliby nowe innowacje. Nierozwiązana wydaje się też kwestia zdolności planistów do mobilizacji wiedzy milczącej.

W swej pełnej wersji model autorów wydaje się pomimo deklaracji zbyt odległy od socjalistycznych wartości demokratycznych. Sądzę, że system oparty na tak daleko idącym centralnym planowaniu grozi rozpadem na klasy i mikroklasy, z uprzywilejowana pozycja planistów i osób posiadających większą niż inni liczbę bonów pracy, w rezultacie tworząc system, który jest zdolny powielić mankamenty realnego socjalizmu.

\section{Jakie planowanie?}

Gdy analizujemy współczesne modele gospodarki planowej, wydaje się, że zasadnicze problemy pozostaja te same, co w chwili upadku Związku Radzieckiego. Już Peter Murell (1991) na podstawie analizy historycznych danych stwierdzil, że tak naprawdę kraje realnego socjalizmu w kwestii alokacji zasobów radziły sobie nieznacznie gorzej od kapitalistycznych. Współcześnie dokonywana przez większość lewicowych ekonomistów implementacja wymiany rynkowej do projektów przyszłej gospodarki socjalistycznej zdaje się znacząco niwelować problem informacji i cenotwórstwa. Nie jest to jednak najważniejsze zagadnienie. Wbrew mitom austriackiej ekonomii Ludwig von Mises wskazywał, że nawet oparta na biurokratycznym planowaniu gospodarka Związku Radzieckiego dobrze radziła sobie z problemem kalkulacji $(1951,136)$. Efektywna przedsiębiorczość i motywacja nie przysługuje zaś wyłącznie przedsiębiorstwom prywatnym. Głównym problemem planowania gospodarczego w krajach realnego socjalizmu była kwestia niedostatecznej innowacyjności i braku wystarczających bodźców do intensywnego wzrostu gospodarczego, określana niekiedy jako problem „konserwatywnej modernizacji” (Brus i Kowalik 1983).

Nie sądzę, by któryś ze współczesnych modeli gospodarki planowej mógł sobie poradzić w pełni z tymi problemami. Dotyczy to także ekonomii partycypacyjnej (Albert i Hahnel 1992, 2006). Autorzy tej propozycji porzucili całkowicie mechanizm rynkowy na rzecz komisji zajmujących się przybliżonym szacowaniem spodziewanej konsumpcji. Ustalanie „cen indykatywnych” (czyli prognozowanych na podstawie negocjacji między producentami i konsumentami w specjalnych komisjach) na wszystkie towary wraz z podejmowaniem wszelkich pozostałych decyzji ekonomicznych ex ante poza jakimiś niewielkimi, lokalnymi społecznościami nie wydaje mi się na dziś poważną i możliwą do realizacji propozycja. Jest to, podobnie jak propozycja Mandela, zbiór pewnych postulatów, które wymagałyby konkretyzacji przez sympatyzujących z nimi ekonomistów. 
Być może, jak sądzą niektórzy komentatorzy, poszczególne elementy omówionych wyżej modeli można by połączyć ze sobą i stworzyć w ten sposób model planowania gospodarczego, który byłby efektywny w okresie przejściowym od kapitalizmu do socjalizmu. Trop ten podjął między innymi David Laibman (2002, 87) konstatując, że potrzebujemy zarówno nowoczesnej technologii zakładanej przez Cockshotta i Cottrella, jak i koncentracji na problemie wiedzy milczącej postulowanej przez Devine’a i Adamana. Obydwa modele zawodza, jeżeli chodzi o obietnicę zniesienia rynku na rzecz całkowitej alokacji ex ante. Ich rzeczywiste funkcjonowanie wymagałoby pewnego rodzaju mechanizmu rynkowego. Nie wdając się szerzej w dyskusję na temat możliwej funkcjonalności systemu zbudowanego z połączenia propozycji powyższych autorów, chciałbym zaproponować nieco inne, chyba mniej radykalne podejście do planowania.

W okresie transformacji na łamach Journal of Comparative Economics odbyła się dyskusja dotycząca wykorzystania planowania indykatywnego w socjalizmie (Brada 1990; Brown 1990). Autorzy sugerowali, że ten typ planowania w warunkach socjalistycznej gospodarki rynkowej może pełnić pomocniczą rolę i zmniejszać niepewność informacyjną związaną z działalnością przedsiębiorstw.

Celem planowania indykatywnego jest koordynacja inwestycji publicznych i prywatnych oraz planowanie produkcji na podstawie prognoz i celów. Podstawowym założeniem tego rodzaju planowania jest przekonanie, że plan może dostarczać ekonomicznie istotnych informacji, których nie jest w stanie dostarczyć mechanizm rynkowy (Nielsen 2008). W odróżnieniu od planowania dyrektywnego typowego dla gospodarek centralnie planowanych, wytyczne nie mają charakteru wiążących formalnie aktów prawnych i postępowanie według wskazań planu nie jest obowiązkowe. Interwencje planistów na rynku wewnętrznym zazwyczaj mają charakter pośredni, np. poprzez kredytowanie firm, których rozwój jest ważny dla gospodarki narodowej.

Ten rodzaj planowania cieszył się dużym powodzeniem po II wojnie światowej w zachodnich krajach kapitalistycznych, między innymi w Wielkiej Brytanii, Francji czy Holandii. Impulsem dla zachodnich ekonomistów była argumentacja Keynesa, który mówił o niepewności panującej na rynkach i potrzebie działań mających na celu zebranie informacji niezbędnych dla stabilniejszego rozwoju (1931, 317). Spośród krajów europejskich planowanie indykatywne było najbardziej rozwijane we Francji (Rosser 2004, 179-203). W różnych formach i z różnym powodzeniem stosowano je także w gospodarkach peryferyjnych (Indie, Korea Południowa, Japonia), a także krótkotrwale w krajach realnego socjalizmu - w latach dwudziestych w Związku Radzieckim, w latach 1945-1948 w Czechosłowacji oraz w latach siedemdziesiątych w Polsce (Brada 1990).

Zwolennicy demokratycznego planowania, których poglądy w poprzednich ustępach nakreśliłem, bliżsi byli planowaniu dyrektywnemu. Socjaliści rynkowi (z wyjątkiem Saula 
Estrina) również nie poświęcali zbyt wielkiej uwagi planowaniu indykatywnemu, zazwyczaj redukując jego rolę do minimum bądź też, tak jak np. Bardhan i Roemer, dość bezrefleksyjnie proponując skopiowanie rozwiązań z różnych krajów, bez zwracania uwagi na to, że zastosowanie tych rozwiązań było możliwe w znacznym stopniu przez kulturę i historię społeczności w nich żyjących. Czy zatem planowanie indykatywne stanowi odpowiedź na zawarte we wstępie pytania? W ramach niniejszego artykułu nie mogę skonstruować rozbudowanej propozycji ekonomicznej, jednakże posługując się dostępną literaturą pragnę sformułować kilka uwag co do możliwości wykorzystania planowania strategicznego w gospodarce okresu przejściowego.

Planowanie indykatywne było różnie oceniane. Wśród ekonomistów nie ma konsensusu co do oceny jego efektywności. Rola planowania w gospodarkach kapitalistycznych od czasów, gdy zaczęto wprowadzać rozwiązania neoliberalne była minimalizowana, aż do niemal całkowitego porzucenia w większości krajów do końca lat osiemdziesiątych ubiegłego wieku. Jego przeciwnicy byli zdania, że był to efekt jego słabej efektywności. Zwolennicy przekonywali, że zostało to umotywowane politycznie i miało związek z tryumfem neoliberalizmu. Kapitaliści w trosce o swój interes klasowy rozpoczęli atak na klasę pracująca i rozpoczęli demontaż sprzyjających jej instytucji. Szerzej o ofensywie neoliberalnej pisał między innymi David Harvey (2007).

Zwolennicy planowania indykatywnego byli przekonani, że jest ono lepsze od tradycyjnej makroekonomicznej polityki fiskalnej oraz zmniejsza niepewność przedsiębiorców zachęcając ich do inwestycji i stymulując wzrost gospodarczy (Harrod 1973). Dane pokazuja, że wzrost PKB w gospodarkach krajów rozwiniętych korzystających z pomocy planistów był niewiele wyższy (średnio ok. 1\%) od gospodarek krajów, w których planowanie nie było wykorzystywane, przy czym wyniki były zdecydowanie najlepsze podczas pierwszych lat planowania (Estrin i Holmes 1990). Większe sukcesy planowanie odnosiło w rozwijających się krajach azjatyckich, przede wszystkim Japonii i Korei Południowej. Zdaniem Leszczyńskiego było to głównie zasługą specyficznej kultury tych krajów, w których zarówno przedsiębiorcy, jak i biurokraci wykazywali się wysokim stopniem zaangażowania w wykonywanie zadań planu (2014, 427-456).

Z pewnościa jednym z głównych warunków powodzenia strategicznych założeń planu jest zaufanie aktorów gospodarczych wobec planistów. W zachodnich krajach kapitalistycznych przedsiębiorców cechowała podejrzliwość wobec rządu i agend blisko z nim związanych. Było to przyczyną niepowodzenia planowania indykatywnego np. w Wielkiej Brytanii (Wood 2000). Kapitaliści w krajach zachodnich czuli się zagrożeni przez wzrastająca rolę państwa i obawiali się, że wprowadzane elementy demokracji ekonomicznej będą skutkowały spadkiem ich zysków (Harvey 2008, 26). W Korei Południowej natomiast kapitaliści byli poczattkowo słabi, 
jednak zostali znacznie wzmocnieni przez politykę ekonomiczną rządu. Po tym jak urośli w siłę, wykorzystali ją do likwidacji państwowych wpływów na gospodarkę (2008, 147-153).

Skoro planowanie i rządowe interwencje wywołują opór kapitalistów, to czy sytuacja poprawi się po zniesieniu własności prywatnej i zmianie sposobu produkcji? Z perspektywy marksistowskiej wydaje się to warunkiem koniecznym, lecz muszę dodać, że nie jest to warunek wystarczający. Trzeba rozważyć, jaki typ własności kolektywnej powinien dominować w nowym sposobie produkcji. Naturalnym kandydatem na wiodący rodzaj firm wydają się kooperatywy pracownicze. Obecnie ich najbardziej rozpowszechnioną formą są omówione w niniejszym artykule firmy typu LMF. Ekonomiści zgadzają się, że potrafią one przetrwać w warunkach kapitalistycznych, choć w niektórych badaniach widoczne jest, że banki faworyzują raczej własność prywatną i w związku z tym np. we Francji lat siedemdziesiątych XX wieku kooperatywy cierpiały na niedokapitalizowanie, przez co traciły na produktywności (Estrin i Jones 1992).

Nie wiadomo, jak firmy typu LMF działałyby w warunkach demokratycznej gospodarki planowej. Jedyne empiryczne dane z otoczenia niekapitalistycznego pochodza z krajów realnego socjalizmu, głównie Jugosławii, gdzie eksperymenty z samorządnościa pracowniczą skończyły się niepowodzeniem (Estrin 1991). Najbardziej zliberalizowaną pod tym względem republika Jugosławii była Słowenia. Przeprowadzono badania na temat funkcjonujących tam w latach osiemdziesiątych firm typu LMF. Okazało się, że niezależnie od wpływu państwowej, autorytarnej biurokracji system nie działał zbyt dobrze. Istniejące firmy w celu ochrony swojej monopolistycznej pozycji blokowały wejście na rynek nowych przedsiębiorstw. Do czasu transformacji przedsiębiorstwa pracownicze zadowalały się popytem na rynku wewnętrznym, nie chcąc rozwijać się i inwestować na rynkach zagranicznych. Wynikało to $\mathrm{z}$ braku inicjatywy $-\mathrm{w}$ systemie tym ani pracownicy, ani menadżerowie nie czuli się odpowiedzialni za swoje zakłady pracy, brakowało pracy zespołowej, świadomości bycia częścią kolektywu - ogólnie rzecz biorąc cech, którymi odznaczają się pracownicy japońskich i pozostałych odnoszących sukcesy na świecie firm (Petrin i Vahcic 2000, 112). Podobne problemy występują jednak często także w kooperatywach działających w warunkach kapitalistycznych (Tjosvold 1998).

Rozwiązaniem, przynajmniej częściowym, tych problemów mogłaby być realizacja marksistowskiego postulatu kontroli pracowniczej nad zatrudnieniem i finansami. W klasycznej formie firmy typu LMF są zarządzane przez wybieranych droga głosowania menadżerów. Moim zdaniem należałoby wzmocnić wpływ pracowników na funkcjonowanie firmy. Kontrolę pracowniczą powinna sprawować załoga, która - poprzez odpowiednie ku temu organy demokracji zakładowej - miałaby wgląd w kondycję finansową przedsiębiorstwa, jego możliwości i zagrożenia, przez co mogłaby decydować o polityce przedsiębiorstwa. W ten sposób załoga przejmuje obszar kompetencji menadżera. Nie podważa ona jednak roli 
ekspertów, których praca jest koniecznościa. Większy udział pracowników w zarządzaniu może pozytywnie wpłynąć na ich motywację i poczucie odpowiedzialności za losy firmy. Trzeba jednak dodać, że zaangażowanie pracowników i efektywne działanie firm LMF w dużej mierze zależeć będzie również od współpracy z innymi podmiotami gospodarczymi. Wykorzystanie potencjału innowacyjnych przedsiębiorstw z pewnością będzie jednym z ważniejszych problemów planowania.

Planowanie indykatywne w krajach kapitalistycznych było najskuteczniejsze tam, gdzie prowadzono dialog społeczny na dużą skalę (Estrin i Holmes 1990). Nie ma powodów, aby inaczej mogło być w gospodarce typu przejściowego. Dlatego potrzebne są komisje „negocjacyjnej koordynacji” w zmodyfikowanej formie. Ich głównym zadaniem nie powinno być wydawanie decyzji o bezpośredniej alokacji zasobów, lecz raczej prowadzenie dialogu społecznego pomiędzy zainteresowanymi efektami planu stronami. Nie decydowałyby o szczegółach polityki firm, ale na drodze deliberacji pomiędzy reprezentantami firm, konsumentów i organów planistycznych miałyby szansę dokonywać korekty ogólnej polityki makroekonomicznej w zależności od szczebla - lokalnego, regionalnego czy krajowego. Dzięki procesowi deliberacji możliwe byłoby budowanie wzajemnego zaufania oraz zachęcanie społeczeństwa do partycypacji w procesie planowania.

Sam plan nie powinien mieć charakteru szczegółowych wytycznych rozwoju. Nie powinno się też zawężać do okresów kilkuletnich (zazwyczaj pięcioletnich) tak jak w przypadku planowania indykatywnego w krajach kapitalistycznych i dyrektywnego w krajach realnego socjalizmu. Powinien mieć raczej charakter hipotezy roboczej, która może ulec weryfikacji i przeformułowaniu (Trocki 1991, 55). Dlatego też lepsze od historycznie stosowanych, przeważnie pięcioletnich byłyby strategiczne plany długoletnie, trwające przykładowo 15 lub 20 lat, które posiadałyby szereg założeń możliwych do szybkiej modyfikacji. Estrin postuluje przykładowo „planowanie rozwijane”, czyli proponuje plany, które w pierwszych latach miałyby szczegółowe założenia, natomiast w kolejnych latach założenia byłyby coraz ogólniejsze, umożliwiając tym samym ich doprecyzowanie z biegiem czasu $(1989,118)$. Same organy planistyczne powinny być tworzone przez niezależnych od rządu ekspertów, których inicjatywa musiałaby się spotkać z uznaniem przedstawicieli suwerennych podmiotów gospodarczych uczestniczących w procesie negocjacji. Miałoby to na celu zapobieżenie niekorzystnej dla gospodarki wysokiej koncentracji władzy w rękach przedstawicieli organów centralnych, przed którą ostrzegał Michał Kalecki (Toporowski 2004, 221).

Na koniec pozostaje odnieść się do kwestii rynków kapitałowych, które współcześnie są fundamentem kapitalizmu monopolistycznego (Foster i McChesney, 2014). Realizacja wytycznych planowania strategicznego o charakterze indykatywnym jest w zasadzie zależna tylko od dobrej woli aktorów gospodarczych. Z drugiej strony działalność preferowanych w mojej propozycji firm typu LMF w dużym stopniu zależna jest od kredytowania przez banki. 
W związku z tym sądzę, że dla pomyślnej realizacji założeń planu konieczna jest państwowa i społeczna kontrola nad instytucjami finansowymi. W odróżnieniu od socjalistów rynkowych nie sądzę jednak, by możliwa była prosta imitacja sprawdzonych historycznie modeli takich jak japońskie kairetsu. Zerwanie z kapitalistycznym sposobem produkcji wymaga na wstępie nacjonalizacji banków, po to żeby kapitał finansowy nie blokował finansowania kooperatyw. Władza państwa nad bankowościa powinna być jednak ograniczona, ponieważ zbyt duża koncentracja władzy skutkowałaby prawdopodobnie możliwością prowadzenia przez biurokrację rządową samodzielnej polityki inwestycyjnej z pominięciem komisji zajmujących się dialogiem między podmiotami gospodarczymi. Wydaje się więc, że na poziomie lokalnym powinno tworzyć się banki spółdzielcze, które kredytowałyby kooperatywy. Natomiast banki państwowe mogłyby operować na poziomie centralnym, wspierając strategiczne projekty ważne dla bezpieczeństwa kraju np. w obszarze energetyki, oraz wspierać inwestycje zagraniczne.

\section{Konkluzja}

W niniejszym artykule przedstawiłem kilka modeli ekonomicznej organizacji społeczeństwa alternatywnych zarówno wobec gospodarki kapitalistycznej, jak i gospodarki opartej na biurokratycznym centralnym planowaniu. Projekty socjalizmu rynkowego niweluja w pewnej mierze bolączki systemu opartego o centralne planowanie. Natomiast problemem najczęściej w nich występującym jest zbyt duże zaufanie do mechanizmu rynkowego oraz brak dobrego systemu koordynacji gospodarczej niezbędnego moim zdaniem do budowy systemu opartego na zasadach demokracji ekonomicznej. Istniejące projekty demokratycznego planowania cechuje z kolei wysoki poziom ogólności i brak precyzji co do szczegółów procesu planowania. Pozytywnym aspektem, który wyróżnia te modele spośród innych, jest dążenie do tego, aby szerokie warstwy społeczeństwa brały udział w polityce gospodarczej. Jednakże nastawienie na oddolna demokratyzację wywołuje problem konieczności podejmowania bardzo dużej liczby decyzji ekonomicznych. Proponowane przyśpieszenie procesu decyzyjnego poprzez komputeryzację i centralizację nie wydaje się do końca trafione. Po pierwsze, w praktyce znosi ono konieczność demokratycznych procedur w procesie planowania. Po drugie, ignoruje ono zagadnienie wykorzystania wiedzy milczącej.

W nowym, alternatywnym wobec kapitalizmu sposobie produkcji, który określam jako okres przejściowy od kapitalizmu do socjalizmu, mechanizm rynkowy mimo swoich wad jest trudny do zastąpienia. Istnienie wymiany rynkowej oraz działanie sił popytu i podaży jest ważne dla poradzenia sobie z problemami informacji, innowacji i przedsiębiorczości. Zasadne wydaje się również współdzielenie z socjalistami rynkowymi poglądu zakładającego konieczność oparcia gospodarki o firmy zarządzane przez pracowników. Rola pracowników powinna 
zakładać ich aktywny udział w polityce przedsiębiorstwa. Jednak oprócz tego konieczny jest mechanizm koordynacji polityki inwestycyjnej niezależnych podmiotów gospodarczych w celu polepszenia sytuacji informacyjnej oraz szybszego wzrostu gospodarczego całego kraju. $\mathrm{Na}$ chwilę obecną najlepszym rozwiązaniem byłoby wieloletnie planowanie strategiczne o charakterze indykatywnym. Głównym warunkiem powodzenia planu powinien być dialog społeczny oraz współpraca prowadzona przez niezależnych od rządu przedstawicieli producentów, konsumentów oraz organów planistycznych. Rola państwa powinna skupiać się na prowadzeniu polityki fiskalnej oraz kredytowaniu przedsięwzięć ważnych dla realizacji zadań planu. Proponowane wyżej rozwiązanie zostało przedstawione jedynie w ogólnym zarysie i z pewnościa będzie rozwijane. Nie jest to też rozwiązanie idealne - wymaga bowiem świadomego zaangażowania aktorów gospodarczych, odpowiednich modeli wzrostu w zależności od kraju/regionu i przede wszystkim rozwiniętej, radykalnej demokracji politycznej. 


\section{Wykaz literatury}

Adaman, Fikret i Pat Devine. 2006. „The Promise of Participatory Planning: Rejoinder to Hodgson." Economy and Society 35.

Adaman, Fikret i Pat Devine. 2001. „Participatory Planning as a Deliberative Democratic Procees. A Response to Hodgson Criticque." Economy and Society 30.

Adaman, Fikret i Pat Devine.2002. „A Reconsidaration of the Theory of Entrepreneurship: A Participatory Aproach." Review of Political Economy 23.

Agafonow, Alejandro. 2012. "The Austrian Dehomeginization Debate, or the Possibility of a Hayekian Planner." Review of Political Economy 24.

Albert, Michael i Robert Hehnel.2006. „Participatory Planning.” Science and Society 56.

Albert, Michael i Robert Hehnel.1992. „In Defence of Participatory Economics.” Science and Society 66.

Andreani, Tony. 2008. Market Socialism: Problems and Models. W Critical Companion to Contemporary Marxisms, red. Jacques Bidet i Stathis Koulevakis. Boston: Routledge

Bardhan, Pranab i John Roemer. 1992. „Market Socialism: A Case for Rejuvenation.” The Journal of Economic Perspectives 6.

Bardhan, Parnab i John Roemer. 1993. Market Socialism: The Current Debate. Oxford: Oxford University Press.

Bewster, Lew. 2004. „Towards a New Socialism?” Quaterly Journal of Austrian Economics 7.

Brada, Josef. 1990. „Indicative Planning in Socialist Economies: Does It Have a Role?” Journal of Comparative Economics 14.

Brada, Josef i Saul Estrin. 1990. „Advances in the Theory and Practice of Indicative Planning.” Journal of Comparative Economics 14.

Brown, Stuart.1990. „Indicative Planning in Socialist Economies: Does It Have a Role?Discussion." Journal of Comparative Economics 14.

Brus, Włodzimierz i Tadeusz Kowalik. 1983. „Socialism and Development.” Cambridge Journal of Economics 3-4.

Brus, Włodzimierz i Kazimierz Laski.1992. Od Marksa do rynku. Warszawa: WN PWN.

Cockshott, Paul. 2009. „A Reply to Bewster: A Response to the Critique of Towards a New Socialism by the Right Wing Economist Bewster." http://reality.gn.apc.org/econ/replytobrewster.pdf.

Cottrell, Allin i Paul Cocskhott.1993. Toward a New Socialism. Notthingam: Spokesman.

Cottrell, Allin i Paul Cockshott. 1989. „Labour Value and Socialist Economic Calculation.” Economy and Society 18.

Cottrell, Allin i Paul Cockshott. 2006. „Why Labour Time Should Be the Basis of Economic Calculation." Mimeo.

Cottrell, Allin i Paul Cockshott. 2005. „Reflections on Economic Democracy.” Reasearch on Political Economy 22.

Devine, Pat.1992. „Market Socialism or Participatory Planning?” Review of Radical Political Economy 24(67).

Devine, Pat. 1988.Democracy and Economic Planning. Cambridge: Westview Press.

Estrin, Saul i Peter Holmes. 1990. „Indicative Planning in Developed Economies.” Journal of Comparative Economics 14.

Estrin, Saul i Julian Le Grand.1989. Market Socialism. Oxford: Clarendon Press. 
Estrin, Saul i Derek Jones. 1992. „Viability of Employee-Owned Firms: Evidence of France.” Industrial and Labor Relations Review 45.

Foster, John i Robert McChesney. 2014. Kryzys bez końca. Tłum. Grzegorz Konat. Warszawa: Instytut Wydawniczy Książka i Prasa.

Hardt, Michael i Antonio Negri.2005. Imperium. Tłum. Adam Kołbaniuk i Sergiusz Ślusarski. Warszawa: Wydawnictwo W.A.B.

Hardt, Michael i Antonio Negri. 2012. Rzecz-pospolita: Poza wtasność prywatna i dobro publiçne. Tłum. Praktyka Teoretyczna. Kraków: Korporacja ha!art.

Harrod, Roy. 1973. Economic Dynamics. London: Macmilian.

Hodgson, Geoffrey.2005a. „Knowledge at Work: Some Neoliberal Anachronisms.” Review of Social Economy 56.

Hodgson, Goeffrey. 2005b. „The Limits to Participatory Planning: A Reply to Adaman and Devine." Economy and Society 34.

Hodgson, Goeffrey. 1998. „Socialism Against Markets? A Critique of Two Recent Proposals.” Economy and Society 27.

Horvat, Branko. 1989. „The Pure Labour Theory of Prices and Interests.” European Economic Review 33.

Husson, Michel. 2011. Kapitalizm bez znieczulenia. Tłum. Zbigniew Marcin Kowalewski. Warszawa: Instytut Wydawniczy Książka i Prasa.

Jossa, Bruno. 2014. „On Producer Cooperatives and Socialism.” International Critical Thought 4.

Jossa, Bruno. 2012. „Cooperative firms as a New Form of Production.” Review of Radical Political Economy 24.

Jossa, Bruno. 2014. Producer Cooperatives as a New Form of Production. New York: Routledge.

Jossa, Bruno. 2009. „Gramsci and the Labor Management-Firm.” Review of Radical Political Economics 41.

Jossa, Bruno. 2005. „Marx, Marxism and the Cooperative Movement.” Cambridge Journal of Economics 29.

Keynes, John Maynard. 1931. „The End of Laissez Faire.” W Essays in Persuasion. London: Macmillian.

Konings, Michael. 2001. „On the Economic Theory of Socialism: Against the Regulations of Social Relations by Market." Resarch on Political Economy 19.

Kornai, Janos. 1990. The Road to a Free Economy. Shifting from a Socialist System: The Example of Hungary. New York: W.W. Norton.

Laibman, David. 2002. „Democratic Coordination: Toward a Working Socialism for the New Century." Science and Society 66.

Lange, Oskar. 1973. „Maszyna licząca i rynek.” W Dzieła, t. 2. Warszawa: PWN.

Lange, Oskar. 1973. „O ekonomicznej teorii socjalizmu.” W Drieła, t. 2. Warszawa: PWN.

Lavigne, Marie. 1989. „A Note on Market Socialism.” Acta Oeconomica 40.

Lavoie, Don.1985. Rivarly and Central Planning: A Re-Examination of The Debate Over Economic Calculation Under Socialism. Cambridge: Cambridge University Press.

Löwy, Michael. 2007. „Eco-Socialism and Democratic Planning.” Socialist Register 43.

Löwy Michael i Joel Kovel. 2007. „Manifest Ekosocjalistyczny.” http:/ / lewica.pl/?id=14440\&tytul=Kovel,-Lowy:-Manifest-ekosocjalistyczny

Malesson, Tom. 2012. Economic Democracy: Towards a Feasible Socialism for $21^{\text {st }}$ Century, Toronto: University of Toronto. 
Mandel, Ernest. 1986. „In Defence of Socialist Planning.” New Left Review 159.

Mandel, Ernest. 1988. „The Myth of Market Socialism.” New Left Review 169.

Miller, David. 1991. Market, State and Community: The Theorethical Foundations of Market Socialism. Oxford: Clarendon Press.

Milonakis, Dmitros.2003. Market Socialism: A Case for Rejuvenation or Inspired Alchemy? Oxford: Oxford University Press.

Mises, Ludvig von. 1951. Socialism: An Economic and Sociological Analysis. New Haven: Yale University Press.

Murell, Peter. 1991. „Evolution in Economics and in The Economic Reform of The Centrall Planned Economies."

http://econweb.umd.edu/ murrell/articles/Evolution\%20in\%20Economics.pdf

Nielsen, Klaus. 2008. „Indicative Planning.” W The New Palgrave Dictionary of Economics, red. Steven N. Darlauf i Lawrence E. Blume. Palgrave Macmillian. http://www.dictionaryofeconomics.com/article?id=pde2008_I000060.

Nijkamp, Peter.2000. „Entrepneurship in a Modern Network Economy.” Reaserch Memorandum 42.

Nove, Alec. 1983. Economics of Feasible Socialism. New York: Routledge.

Nove, Alec. 1991. Economics of Feasible Socialism Revisited. New York: Routledge.

Petrin, Tea i Ales Vahcic. 2000. „Employee Involvment and the Modern Firm.” W Equality, Participation, Transition: Essays in Honour of Branko Horvat, red. Vojmir Franicevic i Milica Uvalic. London: Macmilian Press.

Polanyi, Michael. 1967. The Tacit Dimension. London: Routledge.

Rosser, John i Marina Rosser. 2004. Comparative Economics in Transforming World Economy. Boston: The MIT Press.

Temkin, Gabriel. 2008. Dyskusje o gospodarce socjalistycznej: Marks-Lange-Mises-Hayek. Warszawa: Polskie Towarzystwo Ekonomiczne.

Tjosvold, Dean. 1998. „Making Employee Involvment Work: Cooperative Work and Controversy to Reduce Costs." Human Relations 51(2).

Toporowski, Jan. 2004. „Kalecki’s Arguments for Socialism.” W Kalecki's Economics Today, red. Zdzisław Sadowski i Adam Szeworski. London: Routledge.

Trocki, Lew. 1991. Zdradzona rewolucja: Cåym jest ZSRR $i$ dokad żmierza. Warszawa: Oficyna Wibet.

Walker, Donald. 1987. „Walras'es Theories of Tatonnement.” Journal of Political Economy 95.

Wood, Stewart. 2000. „Why »Indicative Planning« Failed: British Industry and the Formation of National Economic Development Council (1960-1964)." Twentieth Century British History 11.

Vanek, Jaroslav. 1971. „Some Fundamental Considerations on Financing and the Form of Ownership Under Labor Managament." W The Labor Managemnt Economy: Essays by J. Vanek. Ithaca: Cornell University Press. 
Damian Winczewski - Absolwent Wydziału Nauk Społecznych UG. Obecnie doktorant w Instytucie Filozofii Wydziału Humanistycznego Uniwersytetu Szczecińskiego. Zajmuje się głównie filozofią marksistowską oraz heterodoksyjną ekonomia polityczną, ze szczególnym uwzględnieniem post-keynesowskiej teorii pieniądza i neomarksistowskimi koncepcjami wzrostu gospodarczego.

\section{DANE ADRESOWE:}

Instytut Filozofii

Uniwersytet Szczeciński

ul. Krakowska $71-79$

$71-004$ Szczecin

EMAIL: damian.winczewski@gmail.com

CYTOWANIE: Winczewski, Damian. 2015. „W stronę demokracji ekonomicznej. Między socjalizmem rynkowym a demokratycznym planowaniem. " Praktyka Teoretyczna 2(16): 214-239.

DOI: $10.14746 /$ prt.2015.2.12

\section{AUTHOR: Damian Winczewski}

TITLE: Towards economic democracy. Between market socialism and democratic planning

ABSTRACT: The main aim of this article was to answer the question of what planning model is applicable in postcapitalist, transitional period economy based on worker self-management. The works of authors dealing with contemporary political economy shows that labor cooperatives can be an effective way to manage the company and the neo-liberal view on the functioning of companies is anachronistic. Pat Devine and Fikret Adaman tried to prove that the employee enterprises can carry out effective allocation through planning based on negotiations. Paul Cockshott and Allin Cottrell, in turn, argued that the political elements of the negotiations are unnecessary because the plan would require only developed computer technology and cash based on the right values based on the work. Both models have significant limitations, which call into question their functionality. I think a better solution to the problem of effective coordination of employee enterprises is the use of a large-scale indicative planning, which has historically been used in various capitalist countries. Changing the mode of production and the abolition of private property in favour of collective property gives hope that indicative planning will work better than in capitalism.

KEYWORDS: capitalism, socialism, planning, workers cooperatives, production 